\title{
The role of CD36-Fabp4-PPARy in skeletal muscle involves insulin resistance in intrauterine growth retardation mice with catch-up growth
}

Jing Liu ${ }^{1,2}$, Hang Zhao ${ }^{2}$, Linlin Yang ${ }^{3,4}$, Xing Wang ${ }^{3,4}$, Linquan Yang ${ }^{3,4}$, Yuling Xing ${ }^{1}$, Xiuqin Lv' Huijuan Ma $\mathrm{M}^{1,2,3^{*}}$ and Guangyao Song ${ }^{1,2,3^{*}}$

\begin{abstract}
Background: Studies have shown that the high incidence of type 2 diabetes in China is associated with low birth weight and excessive nutrition in adulthood, which occurred during the famine years of the 1950s and 1960s, though the specific molecular mechanisms are unclear. In this study, we proposed a severe maternal caloric restriction during late pregnancy, followed by a post weaning high-fat diet in mice. After weaning, normal and high-fat diets were provided to mice to simulate the dietary pattern of modern society.

Methods: The pregnant mice were divided into two groups: normal birth weight (NBW) group and low birth weight (LBW) group. After 3 weeks for weaning, the male offspring mice in the NBW and LBW groups were then randomly divided into four subgroups: NC, NH, LC and LC groups. The offspring mice in the NC, NH, LC and LC groups were respectively fed with normal diet, normal diet, high-fat diet and high-fat diet for 18 weeks. After 18 weeks of dietary intervention, detailed analyses of mRNA and protein expression patterns, signaling pathway activities, and promoter methylation states were conducted for all relevant genes.

Results: After dietary intervention for 18 weeks, the expressions of CD36, Fabp4, PPARY, FAS, and ACC1 in the skeletal muscle tissue of the LH group were significantly increased compared with the LC and NH groups $(P<0.05)$. The level of p-AMPK/AMPK in the skeletal muscle tissue of the LH group was significantly decreased compared with the LC and NH groups $(P<0.05)$. CPT1 and PGC-1a protein expressions were up-regulated in the LH group $(P<$ 0.05) compared to the LC group. Additionally, the DNA methylation levels of the PGC-1a and GLUT4 gene promoters in the skeletal muscle of the LH groups were higher than those of the LC and NH groups $(P<0.05)$. However, PPARY DNA methylation level in the LH group was lower than those of the LC and NH groups $(P<0.05)$.

Conclusions: LBW combined with high-fat diets may increase insulin resistance and diabetes through regulating the CD36-related Fabp4-PPARY and AMPK/ACC signaling pathways.
\end{abstract}

Keywords: Low birth weight, CD36, Insulin resistance

* Correspondence: huijuanma76@163.com; sguangyao2@163.com

'Department of Internal Medicine, Hebei Medical University, Shijiazhuang 050017, Hebei, China

Full list of author information is available at the end of the article

(c) The Author(s). 2021 Open Access This article is licensed under a Creative Commons Attribution 4.0 International License, which permits use, sharing, adaptation, distribution and reproduction in any medium or format, as long as you give appropriate credit to the original author(s) and the source, provide a link to the Creative Commons licence, and indicate if changes were made. The images or other third party material in this article are included in the article's Creative Commons licence, unless indicated otherwise in a credit line to the material. If material is not included in the article's Creative Commons licence and your intended use is not permitted by statutory regulation or exceeds the permitted use, you will need to obtain permission directly from the copyright holder. To view a copy of this licence, visit http://creativecommons.org/licenses/by/4.0/ The Creative Commons Public Domain Dedication waiver (http://creativecommons.org/publicdomain/zero/1.0/) applies to the data made available in this article, unless otherwise stated in a credit line to the data. 


\section{Background}

Low birth weight (LBW) is an important indicator of fetal environmental damage during intrauterine growth. According to the statistics of the World Health Organization, more than 20 million newborns weigh less than $2500 \mathrm{~g}$, where the overall incidence of LBW in China is $2.18 \%$, with an increasing trend year by year [1]. LBW not only increases the risk of morbidity and mortality in the perinatal period, but also increases the risk of metabolic diseases in adulthood, such as insulin resistance (IR), type 2 diabetes, and obesity [2-4]. A previous meta-analysis study used 21 previous clinical studies (313,165 clinical samples), and found that LBW individuals have a significantly increased risk of developing type 2 diabetes and IR compared with other birth weights, as well as IR might be the central pathogenesis of these chronic metabolic diseases [5]. Ye et al. observed that catch-up growth in early childhood and disorders involving in glucose and lipid metabolism in adulthood were accompanied by impaired IGFBP3/IGF-1/IRS-1/Akt signaling pathway in the liver [6]. In the early stage of our study, we found that deoxycholic acid and cholic acid levels in the blood of LBW mice were significantly lower than those of normal birth weight mice, suggesting that cholic acid metabolism might play a role in adult type 2 diabetes mellitus caused by LBW [7]. However, the mechanisms inducing IR and the development of diabetes in LBW individuals remain unclear.

Skeletal muscle is the main peripheral tissue of glucose and lipid metabolism stimulated by islets, and plays an important role in maintaining the balance of mechanical energy and quantity. IR in skeletal muscle is an important characteristic of type 2 diabetes. The imbalance between fatty acid uptake and oxidation is the main cause of lipid deposition and IR in skeletal muscle. Mitochondrial injury and fatty acid oxidation (FAO) disorders in skeletal muscle induced by a high-fat diet are important factors of IR. The AMPK/ACC signaling pathway plays an important role in regulation of fatty acid oxidation. CD36, known as the fatty acid translocation enzyme, is a type of single chain transmembrane glycoprotein, and widely expressed in various tissues and cells. As a carrier of fatty acids, CD36 protein expression level is associated with impaired fatty acid uptake, oxidation, and IR $[8,9]$. Besides, CD36 signaling has been reported to regulate FAO by directly modulating AMPK activation [9].

Studies have shown that the CD36- and FABP4mediated lipid transport pathways play important roles in the development of IR and atherosclerosis [3]. Longchain fatty acid (LCFA) is an important ligand of PPAR $\gamma$, which can be activated after transport to the nucleus by the Cd36-Fabp4 pathway, thus promoting glycolysis and lipid metabolism and increasing insulin sensitivity [10, 11]. The uptake of glucose in the skeletal muscles is mainly regulated by insulin-responsive glucose transporter 4 (GLUT4) and PPAR $\gamma$ coactivator-1 $\alpha$ (PGC-1 $\alpha)$. GLUT4 and PGC-1 $\alpha$ can mediate the expression of ATP synthesis and oxidative phosphorylation genes.

The increased susceptibility to diabetes may be largely due to the generation of the $P G C-1$ transcriptional coactivator, accompanied by the phenotypic changes (primarily through epigenetic changes) observed in rat offspring induced by environmental factors in the embryonic period. The changes of the gene sequences are not responsible for the epigenetic regulation of gene expression, and instead, the modifications of gene structure through DNA methylation, chromatin remodeling, and histone modifications can regulate epigenetics.

The mechanisms of CD36 regulating muscle glucose metabolism and IR in LBW mice are unknown. This study aimed to investigate the dynamic changes in insulin sensitivity, the CD36-related Fabp4-PPARY and AMPK/ACC signaling pathways in skeletal muscle tissues, and the relationship between catch-up growth and IR in SGA mice.

\section{Methods}

\section{Animals and experimental design}

The animal experiment was conducted in compliance with the relevant guidelines and regulations and was approved by the Animal Ethics Committee of Hebei General Hospital. Adult ICR mice aged 6-8 weeks were selected for this experiment. After one week of free access to water and adaptive feeding, the female and male mice were raised in the same cage at a ratio of $2: 1$. On the second day, the female mice were observed to determine whether they were pregnant through the presence or absence of vaginal plug, and the appearance of vaginal plug was recorded as 0.5 day of gestatin. On the 12.5 day of pregnancy, ICR pregnant mice were randomly divided into normal birth weight (NBW) group and LBW group.

From the 12.5 day to 18.5 days of pregnancy, the mice in the NBW group was fed with a normal diet (free diet), while the mice in the LBW group was provided with a $50 \%$ diet restriction (intake calculated according to the NBW group). After birth, the number of newborn mice was recorded along with their weights. In order to ensure the balance of breast feeding, the litter number less than 8 were all discarded, and the litter number more than 8 retained 8 according to the principle of removing the highest and the lowest weight.

After 3 weeks, the selected weanlings in the NBW and LBW groups were randomly divided into the following four subgroups $(n=9)$ : the normal birth weight + normal diet group $(\mathrm{NC})$, normal birth weight + high-fat diet group $(\mathrm{NH})$, low birth weight + normal diet group (LC), and low birth weight + high-fat diet group (LH). The mice in the $\mathrm{NC}, \mathrm{NH}, \mathrm{LC}$ and $\mathrm{LH}$ groups were 
respectively fed with normal diet, normal diet, high-fat diet and high-fat diet for 18 weeks. The normal diet D12450J and the high-fat diet D12492 were prepared and purchased from Beijing Huafukang Biotechnology Co., Ltd. (Beijing, China). Among them, normal diet contains $20 \%$ protein, $70 \%$ carbohydrate, $10 \%$ fat, and $3.85 \mathrm{kcal} / \mathrm{g}$ calorific value; high-fat diet includes $20 \%$ protein, $20 \%$ carbohydrate, $60 \%$ fat, and $5.24 \mathrm{kcal} / \mathrm{g}$ calorific value. The timeline of all animal experiments are shown in Fig. 1.

\section{Measurement of glucose metabolic and IR indices}

During 18 weeks of dietary intervention, the body weight and food intake of the mice were recorded every week. Meanwhile, the intra-abdominal glucose tolerance test (IPGTT) was performed at the end of 8,12 , and 16 weeks following intervention. The blood glucose level was measured at $0,15,30,60$, and $120 \mathrm{~min}$; and the area under glucose curve (AUC) was obtained to evaluate the degree of IR. Finally, the mice were sacrificed, and the skeletal muscle tissue was isolated from the mice and preserved at $-80^{\circ} \mathrm{C}$. Serum samples were collected, and then fasting blood glucose (FBG) levels and fasting insulin (FINS) levels were determined using a blood glucose determination kit and immunoradiometric assay, respectively. After that, a Homoeostasis Model Assessment for Insulin Resistance (HOMA-IR) was calculated according to the following formula: HOMA-IR = FINS $(\mathrm{mU} / \mathrm{L}) \times \mathrm{FBG}(\mathrm{mmol} / \mathrm{L}) / 22.5$, where the value was adjusted further through a logarithmic transformation.

\section{Reverse transcription-quantitative polymerase chain reaction ( $R T-q P C R)$}

Total RNA was extracted from skeletal muscle tissue using the RNAsimple Total RNA Kit (TIANGEN DP419, China) and the mRNA expression levels of CD36, Acetyl-CoA carboxylase 1(ACC1), fatty acid synthase $(F A S)$, peroxisome proliferator-activated receptor $\gamma(P P A R \gamma)$, and peroxisome proliferator activated receptor $\gamma$ coactivator- $1 \alpha(P G C-1 \alpha)$ were measured using $2^{-\Delta \Delta \mathrm{Ct}}$ method. The all primers were purchased from Integrated DNA Technology (Table 1). The TaqMan assay reagents and endogenous control were purchased from Applied Biosystems and were used to measure $\mathrm{Ct}$ values using the ABI Prism 7500 PCR system (Applied Biosystems, Shijiazhuang, China). Normalizations of the target gene expression were performed using GAPDH as a reference gene.

\section{Western blot assay}

Total proteins were extracted from the skeletal muscle tissues using the Automatic sample freezing grinder (Shanghai Jing Xin, China, JXFSTPRP-CL). A total of 220 to $250 \mathrm{mg}$ of skeletal muscle tissue was extracted from each sample. $1 \mathrm{~mL}$ protein lysate precooled to $4{ }^{\circ} \mathrm{C}$ was added. The homogenates were centrifuged at $13,000 \mathrm{rpm}$ for $5 \mathrm{~min}$ (3 times) at $4{ }^{\circ} \mathrm{C}$ according to the manufacturer's instructions. The protein concentrations were evaluated using a BCA Protein Quantification Kit (Lot 23,227, ThermoFisher Technology co LTD, USA) following the manufacturer's instructions. After that, 30 $\mu \mathrm{g}$ of protein for each sample was resolved and loaded on a $10 \%$ sodium dodecyl sulfate-polyacrylamide gel, electrophoresed, and subsequently electroblotted onto polyvinylidene difluoride (PVDF) membranes. The membrane was then blocked with $5 \%$ skim milk for $2-4 \mathrm{~h}$ at room temperature and subsequently incubated with primary antibody anti-CD36 1:1000 (Abcam, ab133625), anti-AMPK 1:1000 (arigo Biolaboratories Corp, ARG51172), anti-FAS 1:1000 (Cell Signaling Technology, Inc., 3180), anti-ACC1 1:1000 (Cell Signaling Technology, Inc., 3190), anti-PPAR 1:1000 (Proteintech Group, Inc., 16,643-1-AP), anti-CPT1 1:1000 (Aviva, ARP44796_P050), anti-FABP4 1:1000 (Cell Signaling

Fig. 1 The timeline of animal experiments


Table 1 Primer sequences

\begin{tabular}{|c|c|}
\hline Primer & Sequence $\left(5^{\prime} \rightarrow 3^{\prime}\right)$ \\
\hline PPARY & $\begin{array}{l}\text { F: CTGACCCAATGGTTGCTGATTAC } \\
\text { R: GGACGCAGGCTCTACTTGATC }\end{array}$ \\
\hline Fabp4 & $\begin{array}{l}\text { F: CCCTGCCATTGTTAAGACC } \\
\text { R: TGCTGCTGTTCCTGTITTC }\end{array}$ \\
\hline CD36 & $\begin{array}{l}\text { F: GGCTAAATGAGACTGGGACC } \\
\text { R: CAAACATCACCACTCCAATCC }\end{array}$ \\
\hline FAS & $\begin{array}{l}\text { F: ATCTGGGCTGTCCTGCCTCT } \\
\text { R: CAGTITCACGAACCCGCCT }\end{array}$ \\
\hline ACC1 & $\begin{array}{l}\text { F: GCTAAAGGGCGATCTCAACAAAG } \\
\text { R: TTCTCTCCGTGGTTAGGGTTCT }\end{array}$ \\
\hline PGC-1a & $\begin{array}{l}\text { F: CAAGACCAGGAAATCCGAG } \\
\text { R: TGAAGTCGCCATCCCTTAG }\end{array}$ \\
\hline
\end{tabular}

Technology, Inc., 3544), anti-PGC-1 $\alpha$ 1:1000 (Cell Signaling Technology, Inc., 2178), and GAPDH 1:5000 (bioworld, AP003) overnight at $4{ }^{\circ} \mathrm{C}$, respectively.

The prepared antibody diluent was used to dilute HRP-labeled goat anti-rabbit IgG according to the secondary antibody dilution ratio (1:500-1:10,000). After overnight incubation with the primary antibody, the PVDF membrane was immersed in TBST solution and placed on a shaking table for rinsing ( 3 rinses, $10 \mathrm{~min}$ each). The membrane was then placed in a plastic hybridization bag, treated with the corresponding diluted secondary antibody, and incubated by placing on the shaking table at $37^{\circ} \mathrm{C}$ for $1 \mathrm{~h}$. Protein bands were visualized with a gel imager, and the protein expressions were quantified using the ImageJ software.

\section{DNA methylation}

Genomic DNA from rat skeletal muscle was extracted using the EZ DNA Methylation-Gold ${ }^{\mathrm{Tx}}$ Kit (Beijing Tianmo) according to the manufacturer's instructions. The sequences of all primers were designed using the PyroMark primer design software and synthesized by Sangon Biological Co. Ltd. (Shanghai, China). The sequences of PPARY, PGC-1 $\alpha$, and GLUT4 are shown in Tables 2, 3 and 4.

After that, PyroMark PCR kit (Qiagen) including $50 \mathrm{ng}$ DNA (muscle), PCR primers, Taq enzyme, dNTPs, and

Table 2 Primer design for the PGC-1 a assay

\begin{tabular}{|c|c|}
\hline \multicolumn{2}{|c|}{ PGC-1 $a$ primo* assay, designed by PyroMark, Qiagoi } \\
\hline Amplicon product & \\
\hline Forward primer & TGTAGGAGATTTGAGTTATTATGTGAG \\
\hline Reverse primer & ACCTITAAAAAACTTCAAACATCAC \\
\hline Sequencing primer & GAGTTATTATGTGAGTAGGGTT \\
\hline $\begin{array}{l}\text { Sequence intended } \\
\text { for analysis }\end{array}$ & $\begin{array}{l}\text { TGTAGGAGATTTGAGTTATTATGTGAGTAGGGTT } \\
\text { TCGGTITAGAGTTGGTGGTATTAAAGTGGTIT } \\
\text { TAGTIATAGTGTGATGTTGAAGTTITITAAAGGT } \\
\text { (103 bp) }\end{array}$ \\
\hline
\end{tabular}

Table 3 Primer design for the PPARy assay

\begin{tabular}{|c|c|}
\hline \multicolumn{2}{|c|}{ PPARY primo* assay, designed by PyroMark, Qiagoi } \\
\hline \multicolumn{2}{|l|}{ Amplicon product } \\
\hline Forward primer & TGTGTGATTAGGAGTITTAATTAAAG \\
\hline Reverse primer & ACCTTAATCTCTAAATTATAAAACACC \\
\hline Sequencing primer & TCTAAATTATAAAACACCAAATAAA \\
\hline $\begin{array}{l}\text { Sequence intended } \\
\text { for analysis }\end{array}$ & $\begin{array}{l}\text { GTTTGGGATAGGTTGGGATATTCGGGATTTGATA } \\
\text { TITGGCGGAGTTAACGTGGGAATTAAAAATAGT } \\
\text { TATTTCGGGTTATTTCGGGGATATATATATATA } \\
\text { TATATATATATATATATATATACGCGGGTTTATGT } \\
\text { TATTITGTTGGAGTATT ( } 93 \text { bp) }\end{array}$ \\
\hline
\end{tabular}

Taq Buffer was used for PCR based on the manufacturer's protocols. The PCR conditions were displayed as follows: $95^{\circ} \mathrm{C}$ for $5 \mathrm{~min}$, a total of 50 cycles at $94{ }^{\circ} \mathrm{C}$ for $30 \mathrm{~s}$, followed by $55^{\circ} \mathrm{C}$ for $30 \mathrm{~s}$, then $72{ }^{\circ} \mathrm{C}$ for $30 \mathrm{~s}$, and with a final extension at $72{ }^{\circ} \mathrm{C}$ for $8 \mathrm{~min}$. Finally, the PCR product $(5 \mu \mathrm{l})$ was resolved by electrophoresis on a $1 \%$ agarose gel to confirm identity of the product, and then sent to Sangon Biological Co. Ltd. for sequencing using the PyroMark Q96 ID pyrosequencing machine (Qiagen).

For pyrosequencing, the PPAR $\gamma$ primer and PGC- $1 \alpha$ both target $1 \mathrm{CpG}$ site, as well as the GLUT4 primer targets $4 \mathrm{CpG}$ sites. The PCR products were sequenced, and DNA methylation rations were calculated through determining relative peck heights of cytosine $(C)$ and thymine $(\mathrm{T})$ peaks at each $\mathrm{CpG}$ site. The methylation ratios were calculated as $\mathrm{C} /(\mathrm{C}+\mathrm{T})$, and the data were expressed as percent methylation [12-14].

\section{Statistical analysis}

Results are presented as mean $\pm \mathrm{SD}$. Differences within groups were analyzed using an ANOVA, followed by the Kruskal-Wallis nonparametric test analysis. The value of $P<0.05$ was considered statistically significant. All statistical analyses were conducted with the SPSS statistical software, version 21.0.

Table 4 Primer design for the Glut4 assay

\begin{tabular}{|c|c|}
\hline \multicolumn{2}{|c|}{ Glut4 primo* assay, designed by PyroMark, Qiagoi } \\
\hline \multicolumn{2}{|c|}{ Amplicon product } \\
\hline Forward primer & GTITGGGATAGGTTGGGATAT \\
\hline Reverse primer & AATAACTCCAACAAAATAACATAAAAC \\
\hline Sequencing primer & ATATTAGGGATTTGATATTTGG \\
\hline $\begin{array}{l}\text { Sequence intended } \\
\text { for analysis }\end{array}$ & $\begin{array}{l}\text { GTTGGGATAGGTTGGGATATTCGGGATTTGATA } \\
\text { TITGGCGGAGTTAACGTGGGAATIAAAAATAGT } \\
\text { TATTCGGGTATTCGGGGTATATATATATATA } \\
\text { TATATATATATATATATATATACGCGGGTITATGT } \\
\text { TATTITGTTGGAGTATT (156 bp) }\end{array}$ \\
\hline
\end{tabular}




\section{Results}

\section{Establishment of a LBW model}

In this study, 50\% dietary restriction was ensured for pregnant mice in the middle and late stages of pregnancy (12.5 to 18.5 days). It is clear that the birth weight of offspring mice in the pregnant mice with dietary restriction $(1.30 \pm 0.07 \mathrm{~g})$ was significantly lower than that of pregnant mice with normal diet $(P<0.05)$, indicating that the LBW model was successfully established (Fig. 2A).

\section{LBW offspring develop IR and disrupted glucose regulation}

At the end of the experiment, the final body weight of the mice in the $\mathrm{NH}$ and $\mathrm{LH}$ groups was significantly higher than that in the NC group $(P<0.05)$, and the body weight growth of the four groups is shown in Fig. 2B. Furthermore, there was no statistically significant difference in the weekly dietary intake among the $\mathrm{NC}$, $\mathrm{LC}, \mathrm{NH}$ and LH groups (data not shown).
After weaning, the selected male mice in the $\mathrm{NC}, \mathrm{NH}$, LC and LH groups were fed with different diets for 18 weeks. At the end of 16 weeks, the blood glucose level in the LH group was significantly higher (at 0,30 , and 120 min) than that in the NH group $(P<0.05)$, and the area under the glucose curve (AUC) was consistent with the trend of increasing blood glucose $(P<0.05$, Fig. $2 \mathrm{C}, \mathrm{D})$. At the end of 18 weeks, the serum levels of FBG and FINS in the $\mathrm{NH}$ and $\mathrm{LH}$ groups were higher than those in the NC group $(P<0.05$, Fig. 2E, F). Compared with the NH group, the FBG and FINS levels in the LH group were also evidently higher $(P<0.05)$. Thereafter, the values of HOMA-IR were calculated. The results showed that the values of HOMA-IR in the $\mathrm{NH}$ and $\mathrm{LH}$ groups were significantly higher than that in the NC group $(P<$ 0.05), and the value of HOMA-IR in the LH group was markedly higher than that in the $\mathrm{NH}$ group $(P<0.05$, Fig. 2G). All these results indicated that LBW mice fed with high-fat diet exhibited severely disrupted regulation of glucose and IR in adulthood.

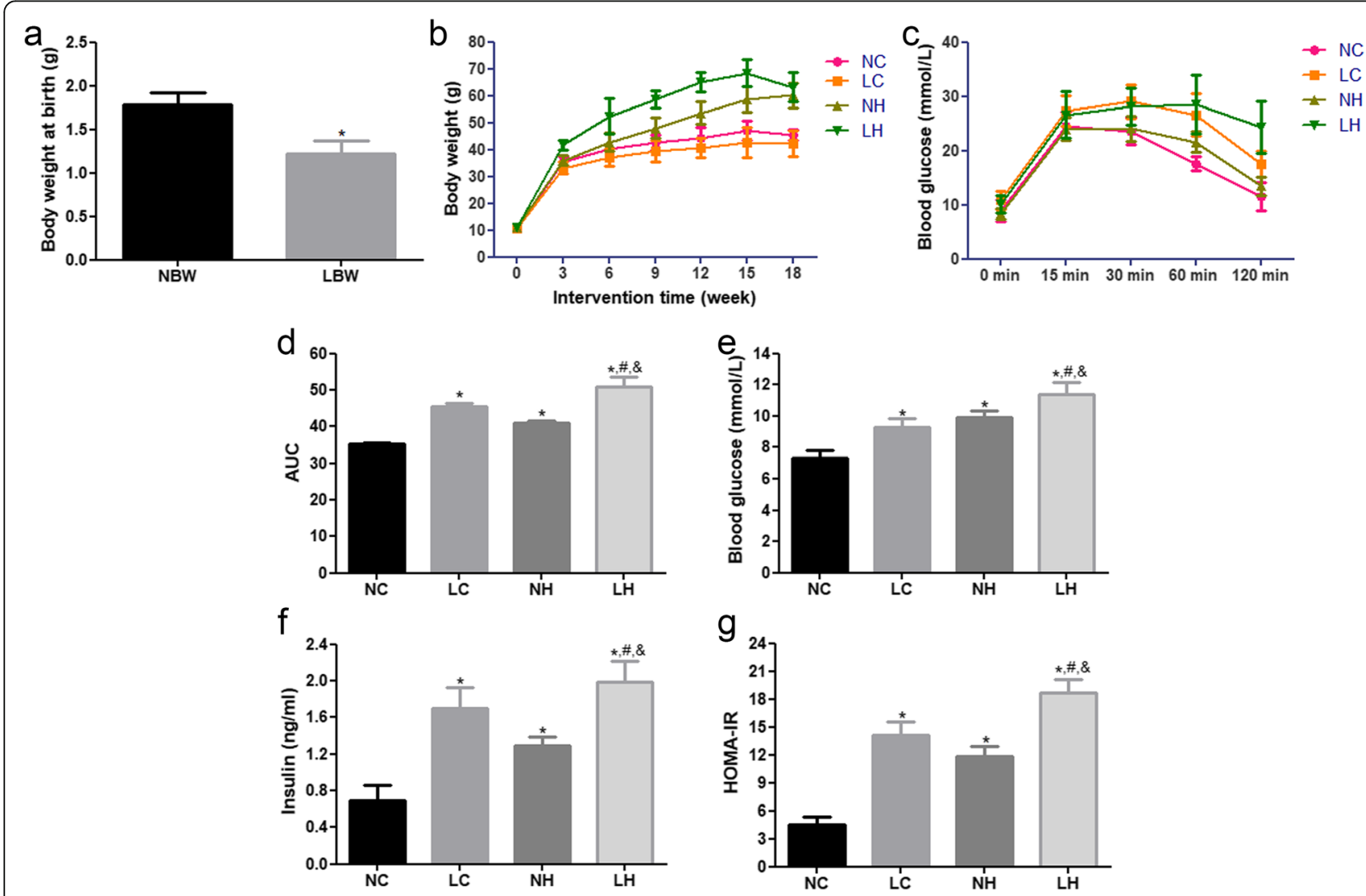

Fig. 2 The body weight, blood glucose, fast insulin, and HOMA-IR in each group at the end of 18 weeks of dietary intervention. A The birth weight of offspring mice was significantly lower than that of pregnant mice without dietary restriction. B The body weight growth of the mice in different groups. C The blood glucose level at each time point of the IPGTT test during the 16 weeks of dietary intervention. D The area under glucose curve (AUC) during the 16 weeks of diet intervention. E The blood glucose in mice of each group.F The insulin in mice of each group. $\mathbf{G}$ HOMA-IR in mice of each group. NC: normal birth weight fed a normal diet; LC: low-birth-weight mice fed with a normal diet; NH: normal birth weight mice fed with a high-fat diet; LH: low birth weight mice fed with a high-fat diet. ${ }^{*} P<0.05$ vs NC group, ${ }^{\#} P<0.05$ vs $L C$ group, ${ }^{\&} P<0.05$ vs $\mathrm{NH}$ group 
Changes in the expression of CD36-Fabp4-PPARY pathway-related proteins and genes in skeletal muscle of the mice in each group

After 18 weeks of high-fat diet intervention, the protein and mRNA expression levels of CD36, Fabp4, PPAR $\gamma, A C C 1$, and FAS in the skeletal muscle tissue of mice were determined. It is clear that the protein expression levels of CD36, Fabp4, PPAR, ACC1 and FAS in the LC group was significantly higher than those in the NC group $(P<0.05$, Fig. 3A-F). Compared with the NC group, the protein expressions of CD36, PPARy, Fabp4, and ACC1 in the NH group were significantly up-regulated $(P<0.05)$; while the protein expressions FAS was evidently down-regulated $(P<0.05$, Fig. 3A-F $)$. However, their protein expressions in the LH group were all significantly upregulated compared with the $\mathrm{LC}$ and $\mathrm{NH}$ groups $(P<$ 0.05 , Fig. 3A-F). Additionally, the trends of CD36, Fabp4, PPAR $\gamma$ and ACC1 mRNA expressions in different groups measured by RT-qPCR were similar with those detected by western blot (Fig. 4A-E). Furthermore, compared with the NC group, the mRNA expression of $P G C-1 \alpha$ was significantly downregulated in the $\mathrm{LC}, \mathrm{NH}$ and $\mathrm{LH}$ groups $(P<0.05)$; while its mRNA expression in the NH group was evidently higher than that in the LC and LH groups ( $\mathrm{P}<0.05$, Fig. 4F).
Changes of expression of AMPK/ACC signaling pathwayrelated proteins in skeletal muscle of the mice in each group

After that, the protein expressions of p-AMPK, AMPK, CPT1, PGC-1 $\alpha$ and GLUT4 were further analyzed by western blot. It is clear that the level of p-AMPK/AMPK was lower in the LC group than that in the NC group $(P<0.05)$, its level in the LH group was decreased compared with the NH and LC groups $(P<0.05$, Fig. 5A, B). For CPT1 and PGC-1 $\alpha$, their expressions were significantly down-regulated in the $\mathrm{LC}, \mathrm{NH}$ and $\mathrm{LH}$ groups compared to the NC group $(P<0.05)$; and their expressions were higher in the $\mathrm{NH}$ and $\mathrm{LH}$ groups than those in the LC group $(P<0.05$, Fig. 5A, C, D). Compared with the $\mathrm{NH}$ group, CPT1 and PGC- $1 \alpha$ expressions were down-regulated in the LH group $(P<0.05$, Fig. $5 \mathrm{~A}, \mathrm{C}$, $D)$. The tendency of GLUT4 protein expression in different groups was similar to that of p-AMPK/AMPK level.

\section{DNA methylation}

The DNA methylation levels of PPAR $\gamma$, PGC- $1 \alpha$ and GLUT4 were further detected. The PPAR $\gamma$ DNA methylation level was increased in the LH group compared with the LC and $\mathrm{NH}$ groups $(P<0.05$, Fig. 6A). For PGC- $1 \alpha$, its DNA methylation rates in the NC, LC,NH and $\mathrm{LH}$ groups were $19 \pm 1 \%, 23 \pm 1 \%, 20 \pm 1 \%$, and $28.67 \pm 1.53 \%$, respectively (Fig. $6 \mathrm{~B}$ ). Compared with the

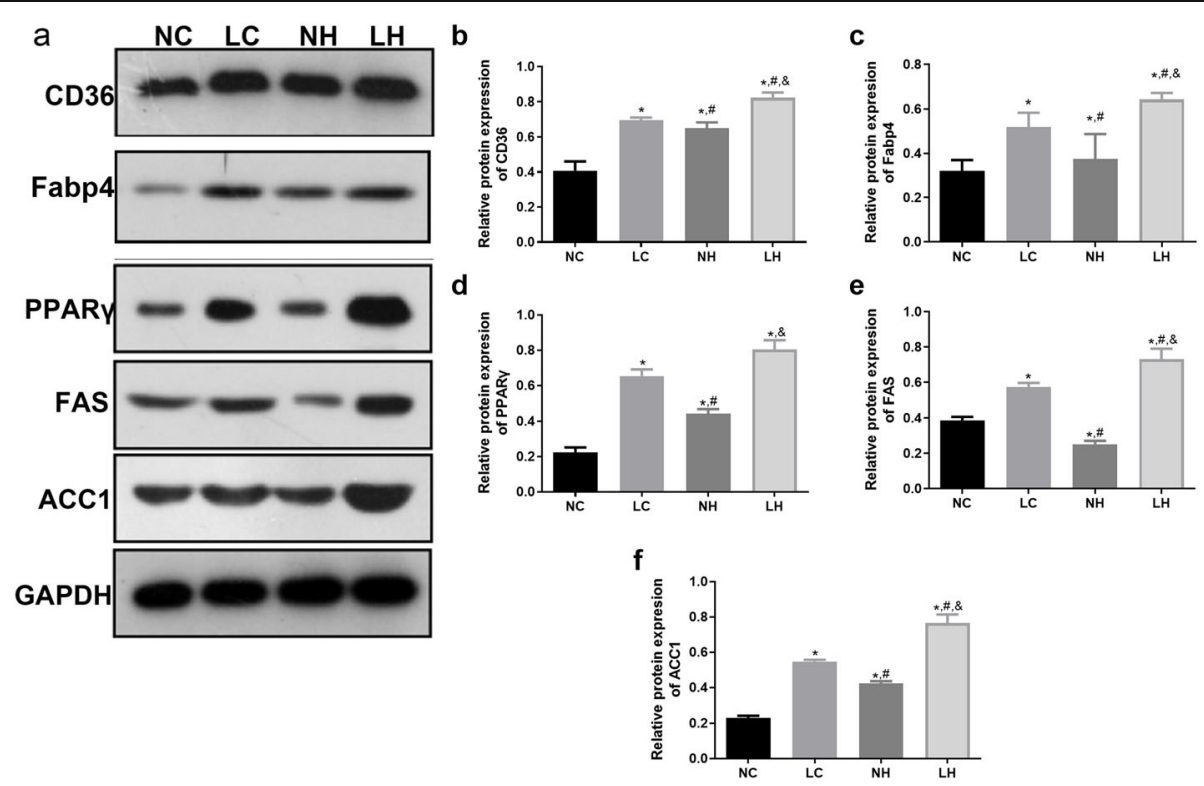

Fig. 3 The protein expressions of CD36, Fabp4, PPARY, ACC1, and FAS in the NC, LC, NH, and LH groups determined by western blot. A The protein bands visualized by western blot. B The relative protein expression of CD36. C The relative protein expression of Fabp4. D The relative protein expression of PPARY. $\mathbf{E}$ The relative protein expression of FAS. $\mathbf{F}$ The relative protein expression of ACC1.Data are $\operatorname{mean} \pm \operatorname{SD}(n=3)^{*} P<$ 0.05 vs NC group, ${ }^{\#} P<0.05$ vs LC group, ${ }^{\&} P<0.05$ vs NH group 
a

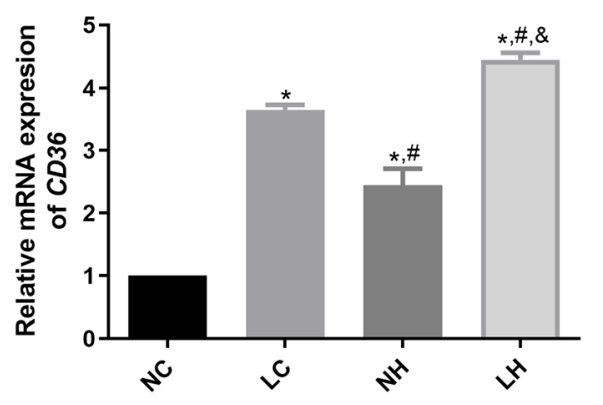

C

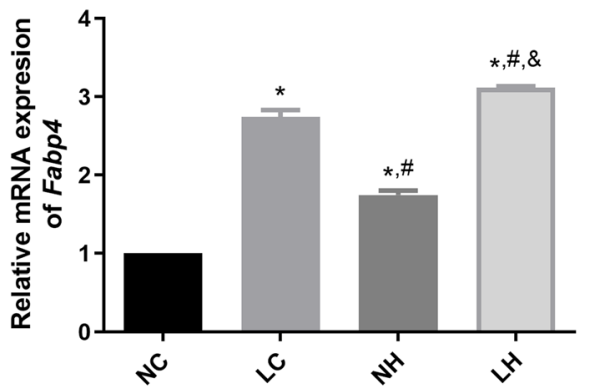

e

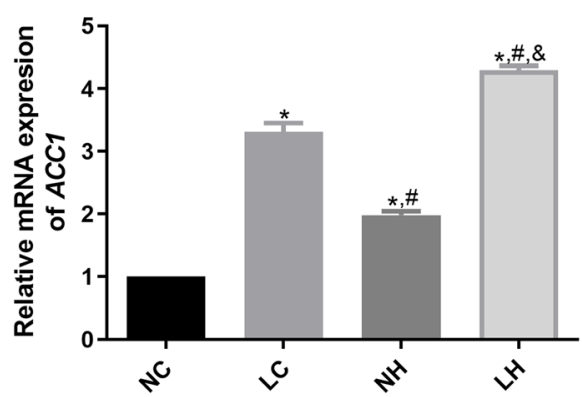

b

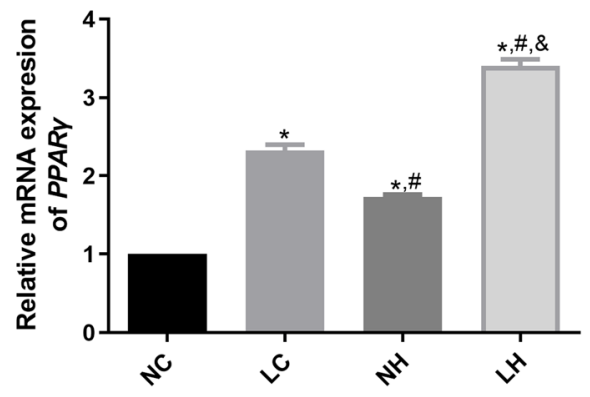

d
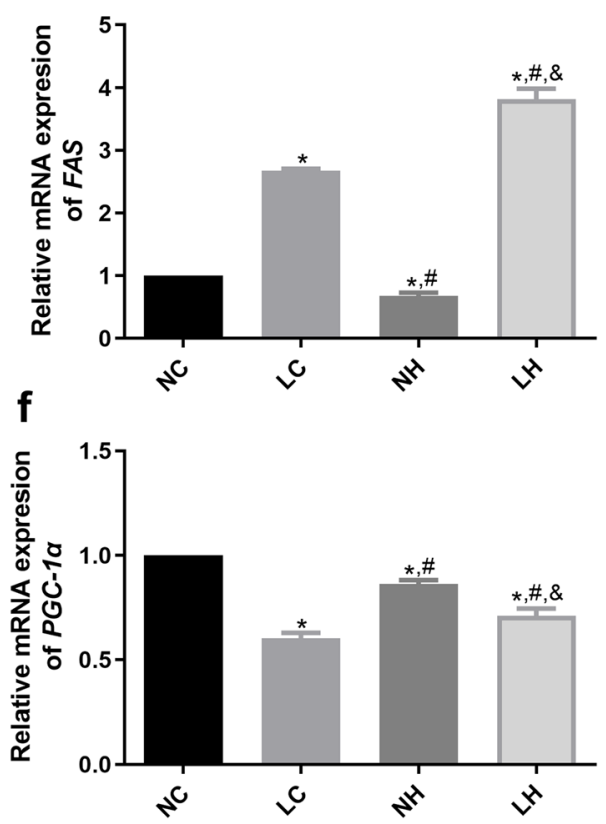

Fig. 4 The mRNA expressions of CD36, PPARY, Fabp4, ACC1, FAS and PGC-1a in the NC, LC, NH, and LH groups measured by reverse transcriptionquantitative polymerase chain reaction. A The mRNA expression of CD36. B The mRNA expression of PPARY. C The mRNA expression of Fabp4. D The mRNA expression of FAS. $\mathbf{E}$ The mRNA expression of ACC1. $\mathbf{F}$ The mRNA expression of $P G C$ - 1 a. Data are mean $\pm S D(n=3)^{*} P<0.05$ vs NC group, ${ }^{\#} P<0.05$ vs LC group, ${ }^{\&} P<0.05$ vs NH group

NC group, the PGC-1 $\alpha$ DNA methylation level in the LC, NH and LH groups were significantly higher $(P<$ $0.05)$, and the level in the LH group was more significant $(P<0.05)$. Additionally, the tendency of GLUT4 DNA methylation level in different groups was similar to that of PGC-1 $\alpha$ DNA methylation level (Fig. 6C).

\section{Discussion}

In our study, the LBW model was constructed by restricting the diet of female mice in the middle and third trimester of pregnancy, similar to the methods used by other investigators [2]. The birth weights of the offspring from mice with dietary restriction were significantly lower than those from mice with normal diet, which demonstrated successful establishment of the LBW mice model. Barker et al. [15] firstly proposed the "thrifty phenotype" hypothesis, stating that the fetal under-nutrition can compel the body to store fat (after improvement of the nutritional environment) rather than muscle. This adaptive adjustment in the fetus is more likely to lead to obesity, IR, and type 2 diabetes [7]. Our study found that in the LBW mice with a highfat diet, glucose regulation was more seriously disrupted in adulthood and IR was more evident, which were consistent with the findings of previous studies $[6,16]$.

Mitochondrial damage and abnormal fatty acid metabolism (especially) usually contribute to IR $[17,18]$. The skeletal muscle represents the main target tissue of 


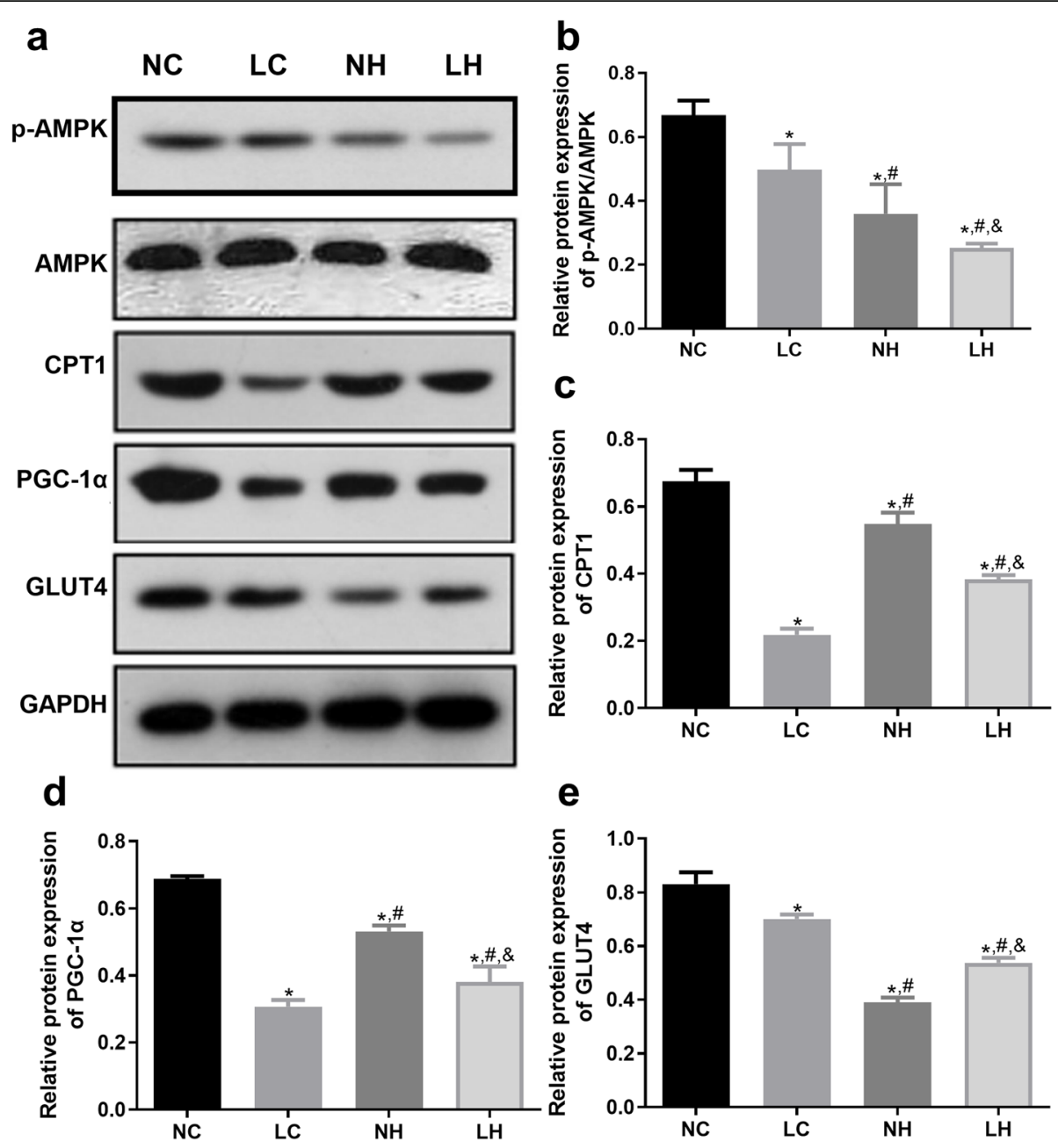

Fig. 5 The protein expressions of p-AMPK, AMPK, PGC-1a, CPT1, and GLUT4 in the NC, LC, NH, and LH groups determined by western blot. A The protein bands visualized by western blot. B The level of p-AMPK/AMPK. C The relative protein expression of CPT1. D The relative protein expression of PGC-1 1a. E The relative protein expression of GLUT4.Data are mean $\pm \mathrm{SD}(n=3)^{*} P<0.05$ vs NC group, ${ }^{\#} P<0.05$ vs $L C$ group, ${ }^{\circledR} P<0.05$ vs $\mathrm{NH}$ group

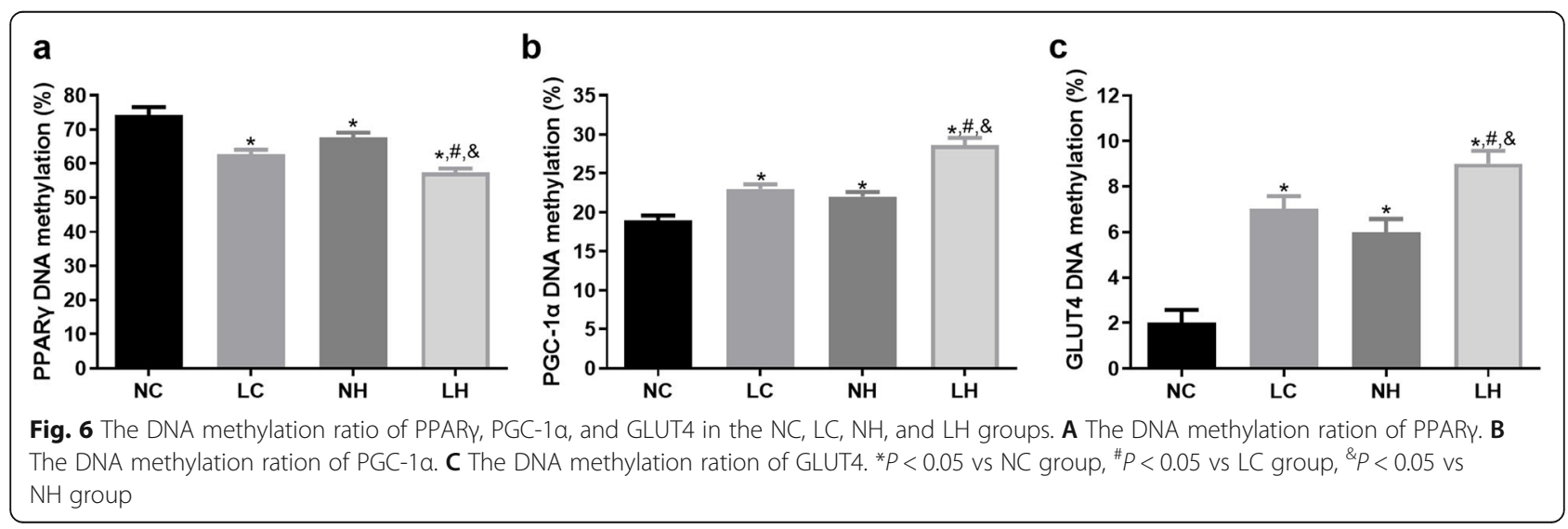


insulin, and is the most important peripheral tissue stimulated by insulin [19]. CD36 is widely expressed in a variety of tissues and cells, and functions as a fatty acid translocation enzyme that is a single chain transmembrane glycoprotein. As a fatty acid transport carrier, the expression of CD36 in skeletal muscle membrane is an important indicator of fatty acid uptake and oxidation activity. CD36 also modulates the role of insulin to stimulate muscle glucose utilization and to influence postprandial glucose metabolism [20]. Samovski et al. indicated that high-fat diet can induce an increase of CD36 protein level in the cell membrane of skeletal muscle cells, and CD36-deficient mice show an increased peripheral tissue sensitivity to insulin, due to reduced skeletal muscle fatty acid uptake [10]. In our study, the level of CD36 in the skeletal muscle tissue of LBW mice with the high-fat diet was significantly increased compared with the LBW mice with the normal diet. Moreover, we found that the CD36 protein level in the skeletal muscle tissue of LBW mice with the high-fat diet was higher than that in the normal weight mice with the high-fat diet. A previous study confirmed the association between early life exposure to malnutrition and the development of long-term metabolic diseases through multiple epidemiological experiments, and proposed the "fetal programming hypothesis" that early intrauterine nutrition can influence fetal genome expression and may persist throughout life [21]. In addition, dietary habits after birth also have important effects on the occurrence and development of metabolic diseases in adulthood. Studies have shown that LBW offspring given a high-fat diet after birth were more prone to hyperinsulinemia and insulin resistance, as well as increased blood glucose levels and lipid deposition in the liver [22, 23], which indicated that disorders of glucose and lipid metabolism in adulthood may result from a combination of intrauterine and postnatal environments. Combined with our results, it can be inferred that high level of CD36 expression in muscle may be associated with the incidence of type 2 diabetes, and IR of the LBW infants with high-fat diets.

Excess fat accumulation may result in the release of free fatty acid (FFA), which can induce IR at high concentrations. CD36 activation with hexarelin can promote mitochondrial activity and biogenesis through enhancing PPAR $\gamma$ and co-activator PGC- $1 \alpha$ transcriptional activity [24]. CD36 has a high affinity for LCFA, and facilitates its entry into the cells, while the binding of LCFA to Fabp4 improves its water solubility [5]. PPAR $\gamma$, an important transcription factor, regulates many transcriptional pathways related to adipogenesis, and can be activated after transport to the nucleus via the CD36Fabp4 pathway. Besides, PPAR $\gamma$ has been reported to play important roles in fetal growth and development, as well as lipid and glucose metabolism. The lack of PPAR $\gamma$ activity is associated with a variety of diseases, such as diabetes, obesity, and high blood pressure. A research of Kelstrup et al. [25] has shown that the decreased gene expression of peroxisome proliferator-activated receptor gamma coactivator 1 alpha (PPARGC1A, also PGC- $1 \alpha$ ) in muscle was related to abnormal insulin function. High-fat overfeeding can increase PPARGC1A DNA methylation in a birth weight-dependent manner in muscle, while this methylation is flexible with different responses of muscle and fat [26]. Our study found that the methylation level of PGC- $1 \alpha$ in the muscle of LBW mice was increased, and was further influenced by highfat diet. Additionally, PGC- $1 \alpha$ is also a coactivator of various transcription factors expressed in skeletal muscle, including PPAR $\gamma$ [27]. Lian et al. have reported that SGA individuals may exhibit high PPAR $\gamma$ expression, which may lead to abnormal fatty acidosis and lipid metabolism disorders [28].

In the present study, we also found that the protein and mRNA expression levels of Fabp4 and PPARY in the skeletal muscle of LBW mice with high-fat diet were ehanced, compared with the normal mice with high-fat diet. After overfeeding with high-fat diets, the reduced methylation of PPARY was found in the LH subject compared to the LC and NH groups. The CD36-Fabp4 pathway can activate PPAR $\gamma$, thereby promoting glycolysis and lipid metabolism. ACC1, FAS, and PPARY have been identified as major regulators of fatty acid biosynthesis. One of the important precursors in the fatty acids biosynthesis is the product of acetyl-CoA carboxylase (ACC), which is known as a mitochondrial fatty acid oxidation inhibitor, thereby playing a vital role in controlling lipid metabolism. FAS is a key enzyme in the synthesis of FFAs, and its abnormal expression is closely associated with the occurrence and development of obesity and IR [29]. Compared with the NH group, the ACC1 and FAS protein expression were up-regulated in the skeletal muscle of the LH group. These suggested that LBW can induce IR and abnormal glucose, while lipid metabolism may be regulated by CD36-Fabp4PPAR $\gamma$, thus affecting the FAO of skeletal muscle.

AMPK activation can stimulate the oxidation of fatty acids in skeletal muscle [30]. AMPK can reduce the synthesis of malonyl-CoA, fatty acids, and other lipids via inhibiting ACC phosphorylation. The fatty acid synthesis can be increased by reducing the inhibitory effect of malonyl-CoA on CPT- $1 \alpha$ oxidative metabolism [31]. CPT1 is a key regulatory enzyme in skeletal muscle mitochondrial FAO, which can catalyze the formation of carnitine to form long-chain acyl carnitine and to activate fatty acid transfer in the mitochondria for oxidation [32, 33]. ACC1, as an upstream factor of CPT1, participates in the FAO process. The $\mathrm{PGC}-1 \alpha$ protein plays a 
major role in regulation of muscle oxidation, which affects the electron delivery system and uncouples the expression of related proteases. Expression of the nuclear respiration factors (NRFs) can regulate mitochondrial respiration and biosynthesis [34-37], which act as key factors in regulation of mitochondrial synthesis [38, 39]. GLUT4 is the entry point for glucose into muscles, and a rate-limiting step in glucose uptake, as well as its down-regulation may have essential effects on the development of decreased glucose tolerance in rats [40]. Interference with PGC-1 $\alpha$ and GLUT4 expression in skeletal muscles has been reported to be closely related to IR in offspring [41]. In addition, the methylation CpG dinucleotides clusters in promoter regions of some genes may contribute to metabolic reprogramming. Zeng et al. [41] demonstrated that the $\mathrm{CpG}$ island methylation was significant in PGC-1 $\alpha$ promoter sequence, as well as the down-regulation of PGC- $1 \alpha$ might lead to the epigenetic modulation of PGC- $1 \alpha$ in 18-month-old female offspring. Another study has shown that malnutrition continued to silence GLUT4 in utero possinly through the action of DNA methylation during aging, thus resulting in the age-related amplification of glucose intolerance.

Previous studies have found that a long-term highfat diet could induce obesity and IR in rat skeletal muscle, consistent with the results from our study, while the level of $\mathrm{p}$-AMPK/AMPK was significantly reduced in mice with high-fat diets $[42,43]$. After the high-fat dietary intervention using, the CPT1, PGC$1 \alpha, \mathrm{p}-\mathrm{AMPK} / \mathrm{AMPK}$, and GLUT4 levels in the skeletal muscle of the $\mathrm{NH}$ and $\mathrm{LH}$ groups were significantly lower than those observed in the NC group, which was consistent with the previous findings [44, 45]. Furthermore, the levels of GLUT4 and PGC- $1 \alpha$ mRNA and protein were decreased, accompanied by the increased methylation levels of GLUT4 and PGC$1 \alpha$, compared with the NC groups. These also indicated that high-fat diet could cause not only heterotopic lipid deposition, but also result in the damage of skeletal muscle mitochondrial function. AMPK can enhance FA uptake and oxidation by promoting localization of the CD36 transporter to the cell membrane [9]. In our study, after the high-fat dietary intervention, CPT1 and PGC- $1 \alpha$ protein expression was significantly reduced in mice, and the level of $\mathrm{p}$ AMPK/AMPK was also decreased in the LH group, which suggested that LBW induced IR might be regulated by $\mathrm{AMPK} / \mathrm{CPT} 1$ and $\mathrm{AMPK} / \mathrm{PGC}-1 \alpha$, thereby affecting the skeletal muscle lipid metabolism and mitochondrial function, and then inhibiting the mitochondrial oxidation of the FAO, eventually leading to the abnormal lipid accumulation.

\section{Conclusions}

In conclusion, our study found that the abnormal glucose tolerance and IR are more evident in mice offspring with LBW after high-fat dietary consumption. Additionally, the CD36-Fabp4-PPAR $\gamma$ and AMPK-ACC-CPT1 signaling pathways may be related to IR and type 2 diabetes caused by catch-up growth.

\section{Acknowledgements \\ None.}

\section{Authors' contributions}

J.L., G.Y.S. and H.J.M. designed the experiments. J.L., H.Z., L.L.Y., X.W., L.Q.Y., Y.L.X, X.Q.L. carried out experiments and analyzed experimental results. J.L. and H.Z. drafted the manuscript. J.L. obtained the fund. G.Y.S. and H.J.M. carefully revised important substantive content of the manuscript. All authors reviewed and approved the final version of the manuscript.

\section{Funding}

This work was supported by Medical science research project of Hebei provincial health commission of China (grant number: 20190030) and grants from National Science Foundation of Hebei province, China (grant number: H2019307108)

\section{Availability of data and materials}

Data are available from the corresponding author upon reasonable request. The datasets used and/or analysed during the current study are available from the corresponding author on reasonable request.

\section{Declarations}

Ethics approval and consent to participate

The animal experiment was conducted in compliance with the relevant guidelines and regulations and was approved by the Animal Ethics Committee of Hebei General Hospital. The study was carried out in compliance with ARRIVE guidelines.

Consent for publication

Not applicable.

\section{Competing interests}

The authors declare that they have no competing interests in this work.

\section{Author details}

'Department of Internal Medicine, Hebei Medical University, Shijiazhuang 050017, Hebei, China. ²Department of Endocrinology, Hebei General Hospital, Shijiazhuang 050051, Hebei, China. ${ }^{3}$ Hebei Key Laboratory of Metabolic Diseases, Shijiazhuang 050051, Hebei, China. ${ }^{4}$ Clinical Medicine Research Center, Hebei General Hospital, Shijiazhuang 050051, Hebei, China.

Received: 4 November 2020 Accepted: 16 December 2021

Published online: 04 January 2022

\section{References}

1. Li N, Li Z, Ye R, Liu J, Ren A. Impact of Periconceptional folic acid supplementation on low birth weight and small-for-gestational-age infants in China: a large prospective cohort study. J Pediatr. 2017;187:105-10. https://doi.org/10.1016/j.jpeds.2017.04.060.

2. Berends LM, Dearden L, Tung YCL, Voshol P, Fernandez-Twinn DS, Ozanne SE. Programming of central and peripheral insulin resistance by low birthweight and postnatal catch-up growth in male mice. Diabetologia. 2018;61(10):2225-34. https://doi.org/10.1007/s00125-018-4694-z.

3. Griffin IJ. Catch-up growth: basic mechanisms. Nestle Nutr Inst Workshop Ser. 2015;81:87-97. https://doi.org/10.1159/000365806.

4. Feng C, Osgood ND, Dyck RF. Low birth weight, cumulative obesity dose, and the risk of incident type 2 diabetes. J Diabetes Res. 2018;2018:8435762.

5. Zhao H, Song A, Zhang $Y$, Zhen $Y$, Song G, Ma H. The association between birth weight and the risk of type 2 diabetes mellitus: a systematic review 
and meta-analysis. Endocr J. 2018;65(9):923-33. https://doi.org/10.1507/ endocrj.EJ18-0072.

6. Peng $\mathrm{P}, \mathrm{Ma}$ C, Wan $\mathrm{S}$, Jin $\mathrm{W}$, Gao Y, Huang T, et al. Inhibition of p53 relieves insulin resistance in fetal growth restriction mice with catch-up growth via activating IGFBP3/IGF-1/IRS-1/Akt signaling pathway. J Nanosci Nanotechnol. 2018;18(6):3925-35. https://doi.org/10.1166/jnn.2018.15036.

7. Ma H, Sales VM, Wolf AR, Subramanian S, Matthews TJ, Chen M, et al. Attenuated effects of bile acids on glucose metabolism and insulin sensitivity in a male mouse model of prenatal undernutrition. Endocrinology. 2017;158(8):2441-52. https://doi.org/10.1210/en.2017-00288.

8. Pietka TA, Schappe T, Conte C, Fabbrini E, Patterson BW, Klein S, et al. Adipose and muscle tissue profile of CD36 transcripts in obese subjects highlights the role of CD36 in fatty acid homeostasis and insulin resistance. Diabetes Care. 2014;37(7):1990-7. https://doi.org/10.2337/dc13-2835.

9. Samovski D, Sun J, Pietka T, Gross RW, Eckel RH, Su X, et al. Regulation of AMPK activation by CD36 links fatty acid uptake to beta-oxidation. Diabetes. 2015;64(2):353-9. https://doi.org/10.2337/db14-0582.

10. Samovski D, Dhule P, Pietka T, Jacome-Sosa M, Penrose E, Son NH, et al. Regulation of insulin receptor pathway and glucose metabolism by CD36 signaling. Diabetes. 2018;67(7):1272-84. https://doi.org/10.2337/db17-1226.

11. Wan Z, Matravadia S, Holloway GP, Wright DC. FAT/CD36 regulates PEPCK expression in adipose tissue. Am J Physiol Cell Physiol. 2013;304(5):C478-84. https://doi.org/10.1152/ajpcell.00372.2012.

12. Fujiki K, Kano F, Shiota K, Murata M. Expression of the peroxisome proliferator activated receptor gamma gene is repressed by DNA methylation in visceral adipose tissue of mouse models of diabetes. BMC Biol. 2009;7(1):38. https://doi.org/10.1186/1741-7007-7-38.

13. Laker RC, Lillard TS, Okutsu M, Zhang M, Hoehn KL, Connelly JJ, et al. Exercise prevents maternal high-fat diet-induced hypermethylation of the Pgc-1alpha gene and age-dependent metabolic dysfunction in the offspring. Diabetes. 2014;63(5):1605-11. https://doi.org/10.2337/db13-1614.

14. Nikzamir A, Palangi A, Kheirollaha A, Tabar H, Malakaskar A, Shahbazian H, et al. Expression of glucose transporter 4 (GLUT4) is increased by Cinnamaldehyde in C2C12 mouse muscle cells. Iran Red Crescent Med J. 2014;16(2):e13426. https://doi.org/10.5812/ircmj.13426.

15. Gluckman PD, Hanson MA, Bateson P, Beedle AS, Law CM, Bhutta ZA, et al. Towards a new developmental synthesis: adaptive developmental plasticity and human disease. Lancet. 2009;373(9675):1654-7. https://doi.org/10.1016/ S0140-6736(09)60234-8

16. Brons C, Jacobsen S, Hiscock N, White A, Nilsson E, Dunger D, et al. Effects of high-fat overfeeding on mitochondrial function, glucose and fat metabolism, and adipokine levels in low-birth-weight subjects. Am J Physiol Endocrinol Metab. 2012;302(1):E43-51. https://doi.org/10.1152/ajpendo. 00095.2011

17. Rupasinghe HP, Sekhon-Loodu S, Mantso T, Panayiotidis MI. Phytochemicals in regulating fatty acid beta-oxidation: potential underlying mechanisms and their involvement in obesity and weight loss. Pharmacol Ther. 2016;165: 153-63. https://doi.org/10.1016/j.pharmthera.2016.06.005.

18. Ingram KH, Hill H, Moellering DR, Hill BG, Lara-Castro C, Newcomer B, et al. Skeletal muscle lipid peroxidation and insulin resistance in humans. J Clin Endocrinol Metab. 2012:97(7):E1182-6. https://doi.org/10.1210/jc.2011-2963.

19. Tunduguru R, Thurmond DC. Promoting glucose transporter-4 vesicle trafficking along cytoskeletal tracks: PAK-Ing them out. Front Endocrinol (Lausanne). 2017;8:329. https://doi.org/10.3389/fendo.2017.00329.

20. Pepino MY, Kuda O, Samovski D, Abumrad NA. Structure-function of CD36 and importance of fatty acid signal transduction in fat metabolism. Annu Rev Nutr. 2014;34(1):281-303. https://doi.org/10.1146/annurev-nutr-071812-1 61220.

21. Barker DJ, Hales CN, Fall CH, Osmond C, Phipps K, Clark PM. Type 2 (noninsulin-dependent) diabetes mellitus, hypertension and hyperlipidaemia (syndrome X): relation to reduced fetal growth. Diabetologia. 1993;36(1):627. https://doi.org/10.1007/BF00399095.

22. Hokama T, Binns C. Trends in the prevalence of low birth weight in Okinawa, Japan: a public health perspective. Acta Paediatr. 2009;98(2):242-6. https://doi.org/10.1111/j.1651-2227.2008.01017.x.

23. Bharati P, Pal M, Bandyopadhyay M, Bhakta A, Chakraborty S, Bharati P. Prevalence and causes of low birth weight in India. Malays J Nutr. 2011; 17(3):301-13.

24. Marechal L, Laviolette M, Rodrigue-Way A, Sow B, Brochu M, Caron V, et al. The CD36-PPARgamma Pathway in Metabolic Disorders. Int J Mol Sci. 2018; 19(5):1529.
25. Kelstrup L, Hjort L, Houshmand-Oeregaard A, Clausen TD, Hansen NS, Broholm C, et al. Gene expression and DNA methylation of PPARGC1A in muscle and adipose tissue from adult offspring of women with diabetes in pregnancy. Diabetes. 2016;65(10):2900-10. https://doi.org/1 $0.2337 / \mathrm{db} 16-0227$

26. Gillberg L, Jacobsen SC, Ronn T, Brons C, Vaag A. PPARGC1A DNA methylation in subcutaneous adipose tissue in low birth weight subjects-impact of 5 days of high-fat overfeeding. Metabolism. 2014;63(2):263-71. https://doi.org/10.1016/..metabol.2013.10.003.

27. Xing $Y$, Zhang J, Wei $H$, Zhang $H$, Guan $Y$, Wang $X$, et al. Reduction of the PI3K/Akt related signaling activities in skeletal muscle tissues involves insulin resistance in intrauterine growth restriction rats with catch-up growth. PLoS One. 2019;14(5):e0216665. https://doi.org/10.13 71/journal.pone.0216665.

28. Lian QX, Deng HZ, Chen KY, Deng H. Role of peroxisome proliferatoractivated receptor (PPARgamma) in metabolic disorders in SGA with catchup growth. Obesity (Silver Spring). 2018;26(1):88-93. https://doi.org/10.1002/ oby.22030.

29. Boden G. Obesity, insulin resistance and free fatty acids. Curr Opin Endocrinol Diabetes Obes. 2011;18(2):139-43. https://doi.org/10.1097/MED. Ob013e3283444b09.

30. O'Neill HM, Holloway GP, Steinberg GR. AMPK regulation of fatty acid metabolism and mitochondrial biogenesis: implications for obesity. Mol Cell Endocrinol. 2013;366(2):135-51. https://doi.org/10.1016/j.mce.2012.06.019.

31. Thomson DM. The Role of AMPK in the Regulation of Skeletal Muscle Size, Hypertrophy, and Regeneration. Int J Mol Sci. 2018;19(10):3125.

32. Vavrova E, Lenoir V, Alves-Guerra MC, Denis RG, Castel J, Esnous C, et al. Muscle expression of a malonyl-CoA-insensitive carnitine palmitoyltransferase-1 protects mice against high-fat/high-sucrose dietinduced insulin resistance. Am J Physiol Endocrinol Metab. 2016;311(3): E649-60. https://doi.org/10.1152/ajpendo.00020.2016.

33. Henique C, Mansouri A, Vavrova E, Lenoir V, Ferry A, Esnous C, et al. Increasing mitochondrial muscle fatty acid oxidation induces skeletal muscle remodeling toward an oxidative phenotype. FASEB J. 2015;29(6): 2473-83. https://doi.org/10.1096/f.14-257717.

34. Zhang L, Zhou Y, Wu W, Hou L, Chen H, Zuo B, et al. Skeletal musclespecific overexpression of PGC-1alpha induces Fiber-type conversion through enhanced mitochondrial respiration and fatty acid oxidation in mice and pigs. Int J Biol Sci. 2017;13(9):1152-62. https://doi.org/10.7150/ ijbs.20132.

35. Agudelo LZ, Ferreira DMS, Dadvar S, Cervenka I, Ketscher L, Izadi M, et al. Skeletal muscle PGC-1alpha1 reroutes kynurenine metabolism to increase energy efficiency and fatigue-resistance. Nat Commun. 2019;10(1):2767. https://doi.org/10.1038/s41467-019-10712-0.

36. Eisele PS, Salatino S, Sobek J, Hottiger MO, Handschin C. The peroxisome proliferator-activated receptor gamma coactivator 1alpha/beta (PGC-1) coactivators repress the transcriptional activity of NF-kappaB in skeletal muscle cells. J Biol Chem. 2013;288(4):2246-60. https://doi.org/10.1074/jbc. M112.375253.

37. Besseiche A, Riveline JP, Gautier JF, Breant B, Blondeau B. Metabolic roles of PGC-1alpha and its implications for type 2 diabetes. Diabetes Metab. 2015; 41(5):347-57. https://doi.org/10.1016/j.diabet.2015.02.002.

38. Finley LW, Lee J, Souza A, Desquiret-Dumas V, Bullock K, Rowe GC, et al. Skeletal muscle transcriptional coactivator PGC-1alpha mediates mitochondrial, but not metabolic, changes during calorie restriction. Proc Natl Acad Sci U S A. 2012;109(8):2931-6. https://doi.org/10.1073/pnas.111 5813109.

39. Nikolic N, Rhedin M, Rustan AC, Storlien L, Thoresen GH, Stromstedt M. Overexpression of PGC-1alpha increases fatty acid oxidative capacity of human skeletal muscle cells. Biochem Res Int. 2012;2012:714074. https://doi. org/10.1155/2012/714074.

40. Duan C, Liu M, Xu H, Tang W, Liu J, Hou L, et al. Decreased expression of GLUT4 in male CG-IUGR rats may play a vital role in their increased susceptibility to diabetes mellitus in adulthood. Acta Biochim Biophys Sin Shanghai. 2016;48(10):872-82. https://doi.org/10.1093/abbs/gmw088.

41. Zeng Y, Gu P, Liu K, Huang P. Maternal protein restriction in rats leads to reduced PGC-1alpha expression via altered DNA methylation in skeletal muscle. Mol Med Rep. 2013;7(1):306-12. https://doi.org/10.3892/mmr.2 012.1134 .

42. O'Neill HM, Lally JS, Galic S, Thomas M, Azizi PD, Fullerton MD, et al. AMPK phosphorylation of ACC2 is required for skeletal muscle fatty acid oxidation 
and insulin sensitivity in mice. Diabetologia. 2014;57(8):1693-702. https://doi org/10.1007/s00125-014-3273-1.

43. Zhao L, Zou T, Gomez NA, Wang B, Zhu MJ, Du M. Raspberry alleviates obesity-induced inflammation and insulin resistance in skeletal muscle through activation of AMP-activated protein kinase (AMPK) alpha1. Nutr Diabetes. 2018;8(1):39. https://doi.org/10.1038/s41387-018-0049-6.

44. Nie Q, Wang C, Song G, Ma H, Kong D, Zhang X, et al. Mitofusin 2 deficiency leads to oxidative stress that contributes to insulin resistance in rat skeletal muscle cells. Mol Biol Rep. 2014;41(10):6975-83. https://doi.org/1 0.1007/s11033-014-3584-9.

45. Liu Y, Song A, Yang $X$, Zhen Y, Chen W, Yang L, et al. Farnesoid X receptor agonist decreases lipid accumulation by promoting hepatic fatty acid oxidation in db/db mice. Int J Mol Med. 2018;42(3):1723-31. https://doi. org/10.3892/ijmm.2018.3715.

\section{Publisher's Note}

Springer Nature remains neutral with regard to jurisdictional claims in published maps and institutional affiliations.

Ready to submit your research? Choose BMC and benefit from:

- fast, convenient online submission

- thorough peer review by experienced researchers in your field

- rapid publication on acceptance

- support for research data, including large and complex data types

- gold Open Access which fosters wider collaboration and increased citations

- maximum visibility for your research: over $100 \mathrm{M}$ website views per year

At BMC, research is always in progress.

Learn more biomedcentral.com/submissions 